\title{
The Effectiveness of Industrial Revolution 4.0 on Labours in Industry Enterprises in Thai Nguyen Province, Viet Nam
}

\author{
Nguyen Thi Oanh, Phung Tran My Hanh, and Nguyen Thi Dung
}

\section{ABSTRACT}

The Industrial Revolution 4.0 has much effectiveness both positive and negative sides on labours in Thai Nguyen province; is one of the political, economic and educational centers of the Northern mountainous midland in developing countries like Vietnam. This paper examines the influencing of Industry 4.0 on labours in Industry enterprises by using secondary data. The results show that in the Industrial Revolution 4.0, labour in Thai Nguyen's Industry enterprises had many new job opportunities, the chance improving their qualifications, skills. But the labours had many challenges such as increasing in inequality between groups of labour at different levels.

Keywords: Labour, Industry enterprises, Industrial revolution 4.0, Thai Nguyen province.

\author{
Submitted : April 02, 2021 \\ Published : May 26, 2021 \\ ISSN: $2507-1076$ \\ DOI: $10.24018 /$ ejbmr.2021.6.3.840 \\ Nguyen Thi Oanh \\ Thai Nguyen University of Economics and \\ Business Administration, Thai Nguyen, \\ Vietnam. \\ Phung Tran My Hanh* \\ Thai Nguyen University of Economics and \\ Business Administration, Thai Nguyen, \\ Vietnam. \\ (e-mail: phungtranmyhanh.tueba@ tueba.edu.vn) \\ Nguyen Thi Dung \\ Bac Giang Agriculture and Forestry University, \\ Bac Giang, Vietnam. \\ *Corresponding Author
}

\section{INTRODUCTION}

Thai Nguyen province is one of the political, economic, and educational centres of the Northern mountainous midland in Vietnam. Thai Nguyen province with favourable conditions on geographic location, socio-economic characteristics; has created favourable conditions for the enterprise's development. In addition, with the policies about investment and enterprise development of Thai Nguyen's provincial leaders, many industrial zones and enterprises have established and attracted thousands of labours from other provinces to work; especially with the number of Industrial enterprises and employees who worked in this area increasing annually per year.

In Industry enterprise includes 4 kinds of enterprises such as mining and quarrying enterprise; manufacturing enterprise (Manufacture of food products and manufacture of beverages, Manufacture of textiles, Manufacture of leather and related products...); electricity, gas, steam and air conditioning supply enterprise; and water supply, sewerage, waste management and remediation activities enterprise, still use old and outdated technology, using abundant young labour with low quality, like textile, garment, footwear, ... According to [15], the number of Manufacturing enterprises accounted for $25 \%$ of total enterprises in Thai Nguyen province with many limitations such as small scale, up to $50.06 \%$ of super-sized enterprises, small with capital of only 1-5 billion VND /enterprise in the Industrial Revolution 4.0. The level of science - technology and innovation are still low, unable to participate in the global production value chain ... In addition, according to the survey results, there are $86.24 \%$ of machinery in Industry enterprises of Thai Nguyen province was imported (15.8\% of hand tools use electricity; $67.84 \%$ of machines are operated by people; $2.6 \%$ of machines are controlled by computers), with old technologies in the period 1980-1990; about $82 \%$ of machines and equipment were fully depreciated, with low production efficiency. In Industry 4.0, along with the fundamental requirements of digital technology, smart connections and changing in technology have created both positive and negative impacts on employees in general, and labours in Manufacturing enterprises of Thai Nguyen province in particular.

There are extensive researches on the labours in much kind of organizations in countries in the entire world. Existing study on labours focus mostly on the recent workplace changes and new forms of work organization [2], [3], [9], [16]. According [13], new opportunities to advance manufacturing of high value products are based on innovating the measuring technologies and procedures for Geometrical Quality Control, in particular addressing the training needs since having well trained professionals is an important key. Current studies have empirically investigated necessary skills development for labours in enterprises, organizations and countries in the Industrial revolution 4.0. These were followed by a number of further studies such that of [1], [4]-[6], [8], [11], [12], [14].

This paper aims to clarify the background of Thai Nguyen's labours for Industry enterprise in the Fourth Industrial Revolution. The present analysis provides 
practically useful implications. Based on the results, the article summarizes recent discussion on labours' income and productivity.

\section{METHODOLOGY}

Secondary data of the Thai Nguyen statistics office, regarding the number of acting enterprises, the number of Industry enterprise, the labours who worked in this kind of enterprise, and average employee's income per month in this area in Thai Nguyen province released on annual year was used in order to analyse for this research.

In this research, descriptive statistics utilize numerical and graphical methods to illustrate the number of enterprises, the number of labours and their income per month in Industry enterprise in the data, to summarize the information it reveals and to present that information in a meaningful way.

Inferential statistics uses the data to make estimates, decisions, predictions, or other generalizations about the labours in Industry enterprises in Thai Nguyen in the Fourth Industrial revolution from which the data was obtained.

\section{RESULTS AND DISCUSSION}

A. The Positive Effects of the Industrial Revolution 4.0 on Labours of Industry Enterprises in Thai Nguyen province, Viet Nam

Firstly, the Industry 4.0 creates lots of job opportunities for labours in enterprises and leads to the trend of moving traditional industries that use a lot of labours from developed countries to developing countries [10]. With $61.26 \%$ of the population in working age, it is an advantage for labours in Thai Nguyen province as foreign-invested enterprises operating in the province are increasing (in 2013, there were only 15 foreign investment enterprises, in 2019 the number of foreign-invested enterprises increased to 102 enterprises, an increase of 6.8 times in 6 years), creating favourable conditions for employment for human resources of the region in Northern Midlands and Mountains, especially Thai Nguyen province.

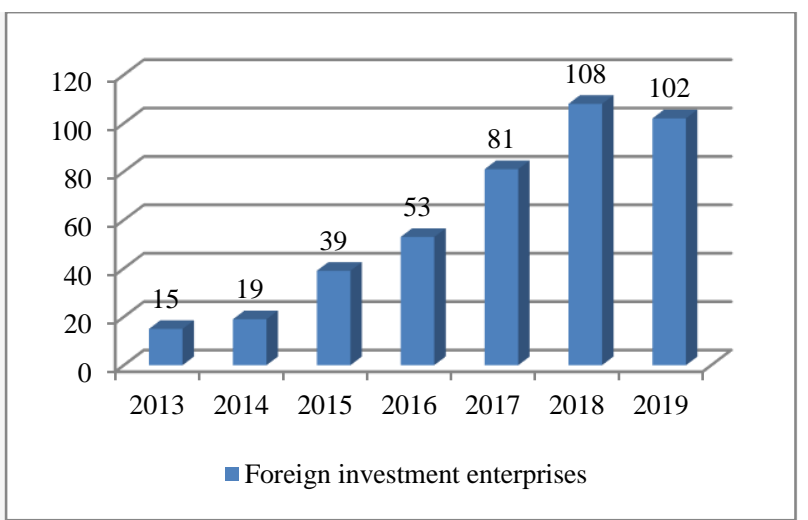

Fig 1. Number of foreign investment enterprise in Thai Nguyen province, Viet Nam (Unit: enterprise).

Secondly, the Industrial Revolution 4.0 creates competitive pressure, and this is an opportunity for each employee working in Industry enterprise in Thai Nguyen province changing. The labours need to improve their qualifications, skills as well as create innovation pressure with the system of education and training institutions of Thai Nguyen province to meet the demand for human resources in the new period. Enterprises need workers to have industrial manners, need qualifications and skills corresponding to problem solving skills, teamwork skills, communication, information technology ... are skills that labours in the Northern Midlands and Mountains in general and Thai Nguyen province in particular are lacking and weak. To meet the new job requires the efforts of the labours themselves and especially the innovation and development of the education and training system.

Thirdly, labour productivity in Thai Nguyen's Industry enterprises tends to be improved due to steps in reducing manual labour and replacing with human-controlled machinery and technology. In Industry 4.0, with developed technology equipment, enterprises can avoid errors in the unnecessary production process, when machines are capable of analysing and predicting technical errors. The efficiency of labour use and production efficiency are improved better due to upgraded logistics services, reducing energy consumption and production materials ... thereby saving production costs for businesses, reducing product prices increase revenue and profit and better meet consumer needs. Employees are used more efficiently by enterprises, freeing their labour force from heavy work and jobs that really require human presence. Increased productivity will create changes in wages and incomes for workers.

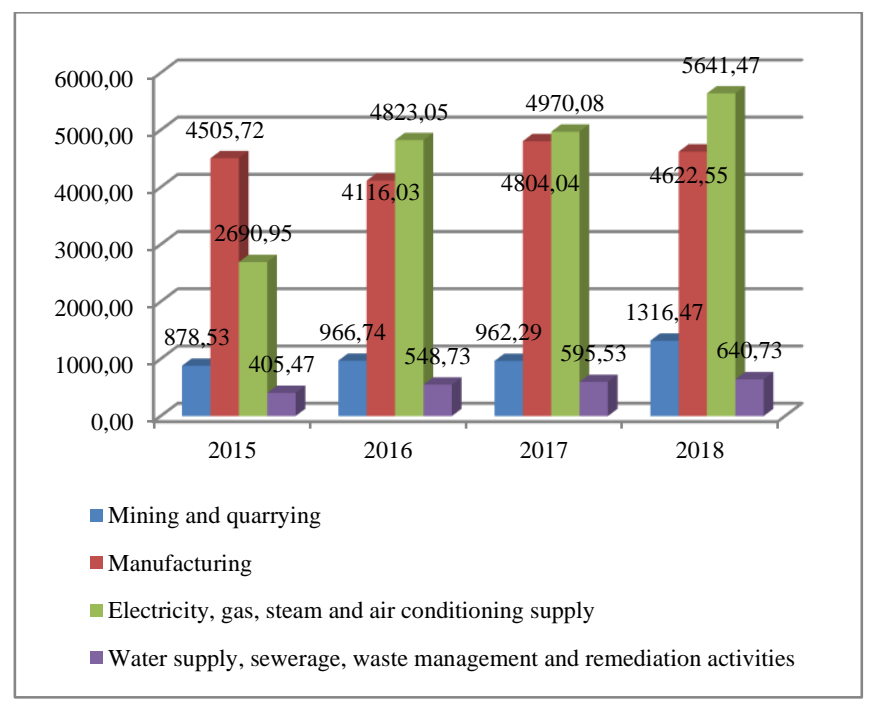

Fig. 2. Labour productivity of Industry enterprises

in Thai Nguyen province, Vietnam (Unit: Million dongs/person).

Fourthly, in Industry 4.0 new job opportunities will appear, the demand will increase for labours with comprehensive knowledge of information technology and indepth knowledge of processes, production, and logistics of businesses industry, especially Industry enterprise. The labour structure in Industry enterprise between industries will change; the demand for labour in the traditional manufacturing industry will decrease, while the labour demand in the high technology Industry enterprise will increase. 
TABLE I: NUMBER OF LABORS IN INDUSTRY ENTERPRISES IN THAI NGUYEN PROVINCE, VIETNAM

\begin{tabular}{|c|c|c|c|c|c|c|}
\hline \multirow[b]{2}{*}{ Industry enterprises } & \multicolumn{2}{|r|}{2016} & \multicolumn{2}{|r|}{2017} & \multicolumn{2}{|r|}{2018} \\
\hline & $\begin{array}{l}\text { Labour } \\
\text { (person) }\end{array}$ & $\begin{array}{l}\text { Average income } \\
\text { thousand dongs } \\
\text { /month) }\end{array}$ & $\begin{array}{l}\text { Labour } \\
\text { (person) }\end{array}$ & $\begin{array}{l}\text { Average income } \\
\text { thousand dongs } \\
\text { /month) }\end{array}$ & $\begin{array}{c}\text { Labour } \\
\text { (person) }\end{array}$ & $\begin{array}{l}\text { Average income } \\
\text { thousand dongs } \\
\text { /month) }\end{array}$ \\
\hline Mining and quarrying & 3,379 & 6,820 & 3,296 & 7,585 & 2,921 & 10,364 \\
\hline $\begin{array}{l}\text { Manufacturing (Manufacture of food products } \\
\text { and manufacture of beverages, Manufacture of } \\
\text { textiles, Manufacture of leather and related } \\
\text { products...) }\end{array}$ & 130,779 & 10,531 & 140,303 & 9,591 & 155,413 & 9,843 \\
\hline $\begin{array}{l}\text { Water supply, sewerage, waste management } \\
\text { and remediation activities }\end{array}$ & 1,611 & 6,822 & 2,082 & 7,028 & 1,834 & 7,843 \\
\hline Total & 137,613 & & 147,613 & & 162,068 & \\
\hline
\end{tabular}

According to Table I, workers are employed in Industry enterprises such as the mining industry; manufacturing (Manufacture of food products and manufacture of beverages, Manufacture of textiles, Manufacture of leather and related products...); electricity, gas, steam, and air conditioning supply; and water supply, sewerage, waste management and remediation activities tended to increase in the period 20152018. In addition, the average income per month of labours working in these Industry enterprises was increasingly day by day.

For enterprises in the mining industry in 2015 , there were 3,479 employees while there were a decreased to 2,921 active employees. Because the environment condition working was toxic, high labour intensity, going deep underground, hard working conditions, average income is higher than some other professions). In Manufacturing enterprise (Manufacture of food products and manufacture of beverages, Manufacture of textiles, Manufacture of leather and related products...), the number of employees increased from 2015 to 2018.

In electricity, gas, steam, and air conditioning supply enterprises, although the number of employees in these enterprises' uneven fluctuation, but also the income of labours has also increased. In 2013, employees working in water supply, sewerage, waste management and remediation activities enterprises had an income of 6,407 thousand dongs / month, whereas in 2018 this rose to 7,843 thousand dongs / month.

B. The Negative Effects of the Industrial Revolution 4.0 on Labours of Industry Enterprises in Thai Nguyen Province, Viet Nam

The Fourth Industrial revolution that is taking place has brought positive impacts on human resources in Industry enterprises, but this "technology wave" also has significant negative impacts on human resources in the Industry enterprises in Thai Nguyen province.

First of all, the qualifications and skills of the labours working in Industry enterprises have not met the requirements of the business. Although in the period of "golden population", high-quality human resources in the province's Manufacturing enterprises are in shortage. In the Industry 4.0, enterprises, including Manufacturing enterprises, increase the need to use workers with knowledge of technology, automation, and soft skills such as communication skills, teamwork, solving situations... and reduce demand for unskilled labour.

Next, Industry 4.0 leads to an increase in inequality between groups of labours at different levels and groups of labours who cannot adapt to new technology in time and at risk of job loss. In the Industry enterprise, unskilled labour in the textiles, footwear and electronics industries is very likely to be displaced as machinery, technology and automation take place on a large scale [7]. According to [18], inequality thus increases between economic sectors, between regions, between urban and rural areas. In addition, the gender inequality between men and women has also increased because men often adapt better than women to changes in science and technology. In the context of the digital revolution, without the policies of Thai Nguyen province as well as the strategies of Industry enterprise to prepare and support female workers, the rate of $58.28 \%$ of female workers working in Industry enterprise (in 2018) potentially impacting income and job loss is enormous.

Last but not least, labours in Industry enterprise in Thai Nguyen province are not ready to adapt the changing in the Industry 4.0 .

TABLE II: VIETNAM'S LABOR RANKING IN THE INDUSTRIAL REVOLUTION 4.0 (RANK/100)

\begin{tabular}{|c|c|c|c|c|c|c|}
\hline & Vietnam & Singapore & Malaysia & Thailand & Philippine & Cambodia \\
\hline \multicolumn{7}{|c|}{ Current labor force } \\
\hline Knowledge-intensive employment & 81 & 1 & 45 & 78 & 50 & 87 \\
\hline Availability of scientists and engineer & 70 & 9 & 7 & 51 & 66 & 96 \\
\hline Digital skills among population & 66 & 6 & 14 & 51 & 42 & 89 \\
\hline \multicolumn{7}{|c|}{ Future Labor Force } \\
\hline $\begin{array}{c}\text { Country capacity to attract and retain } \\
\text { talent }\end{array}$ & 44 & 4 & 12 & 35 & 50 & 38 \\
\hline Quality of universitie & 75 & 50 & 23 & 28 & 47 & 75 \\
\hline Quality of math and science education & 68 & 1 & 16 & 66 & 60 & 86 \\
\hline Quality of vocational training & 80 & 9 & 11 & 59 & 40 & 92 \\
\hline Critical thinking in teaching & 63 & 18 & 14 & 78 & 35 & 49 \\
\hline Active labor policies & 50 & 2 & 9 & 44 & 65 & 68 \\
\hline On-the-job training & 74 & 3 & 12 & 56 & 34 & 86 \\
\hline Hiring and firing practice & 39 & 3 & 10 & 25 & 55 & 27 \\
\hline
\end{tabular}




\section{CONCLUSION}

The results of the study indicated that Industry 4.0 brings both positive and negative effects to labours working in enterprises in general and Industry enterprises in Thai Nguyen province in particular. The positive affecting on labours was bring about many new job opportunities, improved their qualifications, skills to meet requirements in new contexts. In addition, labour productivity in Industry enterprises tends to be improved due to steps in reducing manual labour and replacing with human-controlled machinery and technology.

Besides its positive impacts, the Industrial revolution 4.0 also brings challenges to labours in Industry enterprises such as the qualifications and skills of the labours have not met the requirements of employers. In addition, Industry 4.0 is increased risk in inequality between groups of labours at different levels and is not ready to adapt the changing in the Industry 4.0 .

\section{REFERENCES}

[1] Benešová, A., \& Tupa, J., 2017. Requirements for Education and Qualification of People in Industry 4.0. Procedia Manufacturing. 11, 2195-2202. doi.org/10.1016/j.promfg.2017.07.366.

[2] Boston, J.,1987. Transforming New Zealand's public sector: Labour's quest for improved efficiency and accountability. Public Administration, $\quad 65(4), \quad$ 423-442. doi:10.1111/j.14679299.1987.tb00673.x.

[3] Brown, T., 2006. From Union Inspired to Industry Led: How Australian Labour's Training Reform Experiment Turned Sour. Journal of Industrial Relations, 48(4), 491-505. doi:10.1177/0022185606066141.

[4] Christian, S., 2017. The Challenges of Industry 4.0 for Small and Medium-sized enterprises. A project by the Friedrich-Ebert- Stiftung.

[5] Daniel, B., 2017. Social Innovation Policy for Industry 4.0. A project by the Friedrich-Ebert- Stiftung.

[6] Gerlind, W., Blandine, T., B., Ulrich B., Annemarie M., Gunda N., Guillermo J., S., Beatrice B., 2017. Aftifical Intelligence and Robotics and their Impact on the workplace. IBA Global Employment Institute.

[7] ILO, 2018. Industrial Revolution (IR) 4.0 in Viet Nam: What does it mean for the labour market.

[8] Jan, S., Christopher, R., Erik, S., M., 2017. Industry 4.0 in Danish Industry. Syddansk University, Denmark.

[9] Jerry, W., G., Steven A., E., Ann, M., G., 2002. Principles of human resource development. Perseus Publishing.

[10] Kergroach, S., 2017. Industry 4.0: New Challenges and Opportunities for the Labour Market. Foresight and STI Governance. 11(4), 6-8.

[11] KPMG, 2016. The factory of the future, Industry 4.0 - The challenges of tomorrow.

[12] Paul, J., D., 2016. Reskilling for the fourth Industrial revolution. Formulating a European strategy. Policy paper. 175, 1-16.

[13] Rocha L., Savio E., Marxer M., Ferreira F.,2018. Education and training in coordinate metrology for industry towards digital manufacturing. Journal of Physics: Conf. Series 1044 (2018) 012026. IOP Publishing. doi :10.1088/1742-6596/1044/1/012026.

[14] Silvio, A., Marco, P., Francesco, Q., Marco, Z., Silvia, F., Francesca, N., Stefania, S., 2017. Unito and the challenges of Industry 4.0. University or Toronto, Canada.

[15] Thai Nguyen statistics office. (2020). Thai Nguyen Statistical Yearbook 2019. Thai Nguyen statistics publishing.

[16] Waqas, I. Yasir A., F., Muhammad A., 2016. Effect of Human Resource Management Practices on Employee Performance: A Study of Telecom Sector. Journal of Resources Development and Management. 20, 61-71.

[17] World Economic Forum, 2018. Readiness for the Future of Production Report 2018. Geneva, Turkey.

[18] Zoltán Rajnai; István Kocsis., 2017. Labor Market Risks of Industry 4.0, Digitization, Robots and AI. SISY 2017 - IEEE 15th International Symposium on Intelligent Systems and Informatics. Subotica, Serbia. 343-346. 